\title{
Onset of action of relaxants
}

Induction of anaesthesia must be performed carefully with special attention to the possibility of hypoxia and aspiration of gastric contents. These problems are largely avoided by the proper placement of a tracheal tube and mechanical ventilation. However, the degree of paralysis required for easy laryngoscopy and tracheal intubation is not achieved immediately after the injection of the relaxant drug. The time delay between inducing anaesthesia and securing the airway should be considered a danger period which should be shortened as much as possible

For the past 35 years, succinylcholine has been the drug of choice to achieve profound neuromuscular blockade rapidly. Doses of $1-1.5 \mathrm{mg} \cdot \mathrm{kg}^{-1}$ provide excellent intubating conditions in 60 to 90 seconds ${ }^{1-7}$ Unfortunately, succinylcholine is a depolarizing agent which is contraindicated in certain patients and has annoying side effects in most others. ${ }^{8,9}$ Until the early 1980 's, the non-depolarizing relaxants used in clinical practice had too many cardiovascular side effects and their duration of action was too long to be used effectively to facilitate tracheal intubation. With the introduction of atracurium and vecuronium, it was hoped that the onset of neuromuscular blockade could be reduced considerably compared with older non-depolarizing relaxants. Unfortunately, although significant improvements have been made, onset times have not approached that of succinylcholine..$^{6,10-13}$

In an attempt to identify the factors which influence the onset of neuromuscular blockade, one must consider that the intravenously injected drug must reach the target organ, diffuse from the intravascular space to the site of action, and interact with the receptor before it is taken away from the neuromuscular junction. Understanding these factors might help explain why no drug, including atracurium and vecuronium, and no method of administration, including the priming technique, can match the short onset of action of succinylcholine. Furthermore, certain patient characteristics are likely to affect the onset of blockade, either because potency is altered, or because the factors which govern delivery to, and removal from. the neuromuscular junction are altered.

\section{Access to muscle}

Muscle relaxants are usually injected into a peripheral vein, and carried to their site of action via the blood stream. Thus, the time from administration of a relaxant drug and its effect is modified markedly by circulatory factors.
François Donati PH D MD FRCPC

\section{Cardiac output}

After intravenous injection, the drug is carried to the central circulation where it mixes with venous blood coming from all organs. Then it enters the ride side of the heart, goes through the pulmonary circulation and the left side of the heart to the aorta. The transition time from peripheral venous to arterial circulation depends on cardiac output, Not surprisingly, cardiac output has been identified as a major factor affecting succinylcholine onset time. ${ }^{13}$ The onset time of non-depolarizing relaxants was found to be shorter in infants, who have a relatively large cardiac output, than in older children. ${ }^{14,15}$ Within the adult population, the onset of pancuronium blockade is slower in older individuals, who have a decreased cardiac output compared with younger subjects. ${ }^{16}$ Although the possibility has not been tested, the circulatory effects of the intravenous induction agent are expected to modify the onset of action of relaxant drugs given concurrently. For example, an overdose of thiopentone may be associated with decreased cardiac output, hypotension and prolonged onset time of the relaxant given at induction.

\section{Circulation time to muscle}

Before the drug reaches muscle, the relaxant-containing blood which first appears in the aorta must push the relaxant-free blood ahead of it in the arteries and capillaries. The time involved in this process will depend on the volume of blood contained in the blood vessels concerned and how quickly it circulates, that is, on the distance to the target organ and its blood flow. It follows that the muscles which are closer to the central circulation and have a better perfusion tend to be paralyzed more rapidly than more peripheral, less perfused muscles. For example, the diaphragm was found to be blocked before the adductor pollicis muscle after injection of vecuronium, atracurium, or succinylcholine (Figure 1). ${ }^{17,18}$

\section{Muscle blood flow}

When the relaxant first reaches the neuromuscular junction area, there is a high concentration gradient between the blood and surrounding tissue. Thus, a large proportion

Departments of Anaesthesia, Royal Victoria Hospital and McGill University, 687 Pine Avenue West, Montreal, Quebec H3A IAl. 


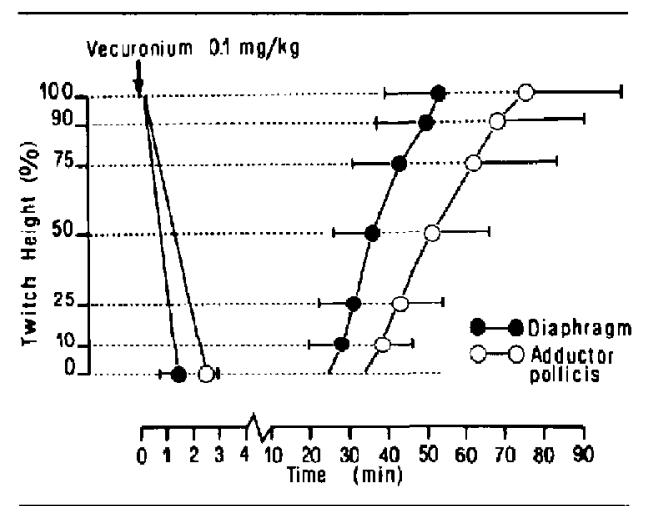

FIGURE 1 Neuronuscular blockade at the diaphragm and the adductor pollicis during onset (left) and recovery (right) after injeclism of vecuronium (from Chauvin et al. ${ }^{17}$ ).

of the relaxant diffuses out of the intravascular space. The time to reach a given drug concentration al the receptor site then depends on how quickly fresh drug arrives, that is on muscle blood flow. In dogs, the onset time of gallamine neuromuscular blockade in the tibialis anterior muscle was found to be shortened by increasing blood flow to the muscle (Figure 2). ${ }^{19}$ The metabolic activity of the muscle affects blood flow, and evoked contractions can be associated with marked increases in blood flow. ${ }^{20}$ It follows that measured onset of neuromuscular blockade is shorter if train-of-four stimulation is used instead of single twitch stimulation. ${ }^{21}$

\section{Access to the receptor}

After the relaxant reaches muscle, it must gain access to the acetylcholine receptor. The rate at which receptors are blocked depends on the affinity of muscle tissue for relaxant drugs, on the rate of diffusion of relaxant molecules from the intravascular space into the synaptic cleft, and on the rate of binding to the receptor.

\section{Affinity of the organ}

The time required to reach a given drug concentration in muscle depends on how avidly the organ takes up the drug, or the ratio of organ to blood concentrations at equilibrium. Muscle relaxants are ionized, water soluble compounds, and their volume of distribution is approximately equal to that of extracellular volume. ${ }^{22}$ In muscle, they do not penetrate cells and their partition coefficient is proportional to the ratio of extracellular volume to total muscle volume, about $0.2-0.4 .^{23,24}$ This relatively small tissue:blood partition coefficient explains why equilibration of relaxants with muscle takes much less time (a few minutes) than equilibration of inhalational agents (one to two hours) with the same tissue.

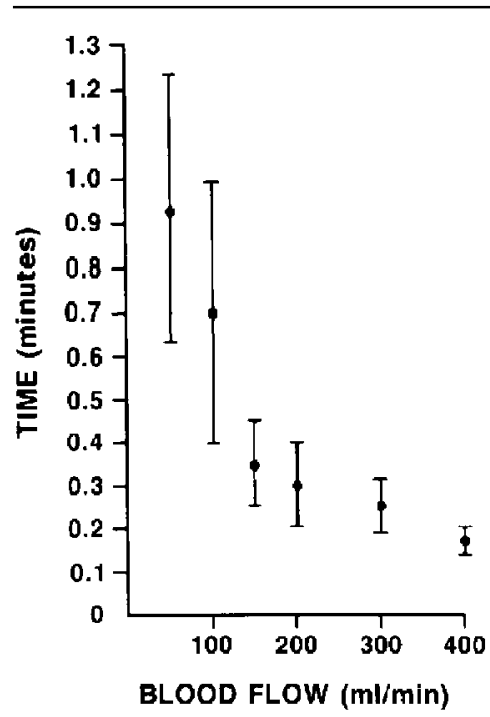

FGURE 2 Effect of blood flow in the femoral artery on the onset time of gallamine neuromuscular blockade in dogs. (From Goat ef at. ${ }^{19}$ ).

\section{Diffusion}

The time required for relaxant molccules to leave the intravascular space and reach the neuromuscular junction should theoretically affect onset time. However, it has been shown that $d$-tubocurarine molecules can move into and leave the synaptic area in a few milliseconds. ${ }^{25}$ Therefore, diffusion time is not expected to contribute significantly to onset time.

\section{Rate of binding}

Onee present in the synaptic cleft, the rate of binding of relaxant molecules to the receptor is extremely rapid and the delay between binding and pharmacological effect is very short. ${ }^{26}$ Thus, these interactions at the molecular level are not expected to affect onset time.

\section{Potency}

All other factors being equal, potent neuromuscular blocking drugs should have a longer onset time. The neuromuscular junction can be regarded as a dense cluster of receptors, and no matter the potency of the relaxant, a large proportion of these receptors ( $>90$ per cent) must be occupied beforc ncuromuscular blockade is complete. ${ }^{27}$ Thus, a critical number of relaxant molecules must reach the neuromuscular junction before the desired effect is manifest. If equipotent doses of relaxant are given, this critical number will be carried in a larger volume of blood if the drug is potent. It follows that since this larger 
volume of blood will take more time to arrive in the vicinity of the neuromuscular junction, potent drugs should have a slower onset. Comparisons of pancuronium and d-tubocurarine onset times suggest that the importance of this effect for $E_{95}$ doses is a few seconds, ${ }^{28}$ and is expected to be even less with larger doses. At present, there is no clinical evidence suggesting that potent drugs, such as vecuronium, have unacceptably slow onset times because of their potency.

\section{Concept of biophase}

The onset of neuromuscular blockade cannot be explained satisfactorily by pharmacokinetic modelling, because there is a discrepancy between plasma concentrations and effect at time zero. To account for the absence of blockade in spite of very high concentrations of relaxant, a biophase, or effect, compartment has been proposed. ${ }^{29,30}$ The rate of entry into the biophase compartment is a measure of its accessibility, which depends on all the factors enumerated above ${ }^{31}$ Interestingly, the estimates of the biophase half-time, which is inversely related to the rate of entry into the biophase, are remarkably constant (3-7 min) for all non-depolarizing relaxants. ${ }^{24.29 .30 .32 .33}$ This suggests that the onset of neuromuscular blockade depends largely on patient characteristics, such as cardiac output, circulation time, and muscle blood flow. ${ }^{31}$ The properties of the relaxants, such as potency, affinity for muscle and diffusion characteristics are less important.

\section{Termination of effect}

The peak effect occurs when the concentration at the neuromuscular junction equals that in the blood perfusing it. This equilibrium is attained rapidly if the factors which promote access to the neuromuscular junction are favourable. It also occurs early if the blood concentrations of the drug decrease rapidly.

The effect of the relaxant starts to decline when the plasma concentration of the drug in the arterial blood decreases below that at the neuromuscular junction. This will occur at a time which is determined by the rate of distribution and elimination of the relaxant. For long and intermediate acting nondepolarizing blackers, elimination processes are too slow to affect onset times significantly. Thus, the time to peak effect is determined to a large cxtent by distribution processes. These occur at approximately the same rate for all non-depolarizing relaxants, because of similarities in structure, ionization and molecular weight. As a result, onset times for intermediate and long-acting relaxants are remarkably similar. ${ }^{34}$ If a subparalyzing dose is administered, the time to maximum blockade is as long as $5-7 \mathrm{~min}$, even for atracurium and vecuronium. ${ }^{12}$ However, succinylcholine is metabolized so rapidly that plasma concentrations fall below those at the neuromuscular junction within $2 \mathrm{~min}$. In patients with abnormal plasma cholinesterase, the time to maximum succinylcholine blockade is $5-6$ min, ${ }^{35,36}$ similar to that of non-depolarizing relaxants. This suggests that the rapid effect of succinylcholine in normal patients is not due to its mechanism of action at the neuromuscular junction, but to its metabolism. The investigational drug BW1090, a non-depolarizing relaxant with a duration of action one-third to one-half that of atracurium, has an onset time of 4-5 min when given in subparalyzing doses, ${ }^{37}$ a situation not markedly different from that of atracurium.

\section{Dose}

The above considerations suggest that for a given drug, the time from injection to maximum effect is independent of dose. However, if the dose is sufficient to abolish twitch height completely, the time from injection to 100 per cent blockade is reduced. ${ }^{12}$ This does not imply that the time to maximum receptor occupancy is decreased. Increasing the dose shortens the delay between injection and the time when the concentration of relaxant at the neuromuscular junction exceeds that necessary to produce 100 per cent blockade. Therefore, time to maximum blockade decreases markedly with dose in the one to three times $\mathrm{ED}_{45}$ range (Figure 3). At doses greater than threc times $\mathrm{ED}_{95}$, the time to 100 per cent blockade does not decrease markedly with increasing dose (Figure 3) ${ }^{3 \mathrm{~B}} \mathrm{At}$ high doses, the limiting factor appears to be the time required for the drug to reach the neuromuscular junction, which in turn depends on cardiac output, the distance of the muscle from the central circulation, and muscle blood flow.

Most potency data on muscle relaxants were obtained using the force of contraction of the adductor pollicis muscle as the response. The same muscle is also often monitored clinically. However, good intubating conditions and adequate surgical relaxation are achieved only if other muscles are paralyzed too. Thus, adductor pollicis blockade is irrelevant unless it is a reliable guide of the intensity of paralysis of other muscles, especially those of the upper airway, the respiratory system and the site of the surgical procedure.

Amongst respiratory muscles, the diaphragm is most resistant to the action of non-depolurizing relaxants. Approximately 1.5-2 times as much vecuronium, atracurium or pancuronium is required to block the diaphragm compared with the adductor pollicis. ${ }^{39,40}$ Thus, complete paralysis of all muscles, including the diaphragm, is not expected with a dose of relaxant that barely blocks the adductor pollicis. Twice as much may be required to block the diaphragm. Furthermore, patients differ markedly with respect to their sensitivity to relaxants. As a 


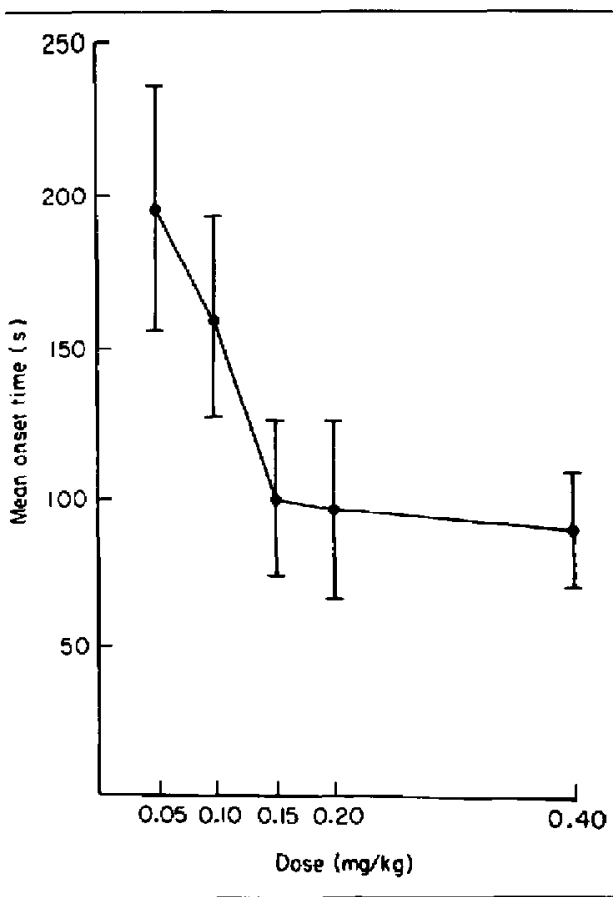

FIGURE 3 Time to maximum blockade versus dose of vecuronium given. Onset time decreases markedly in the one to three times $\mathrm{ED}_{95}$ range ( 0.05 to $0.15 \mathrm{mg} \cdot \mathrm{kg}^{-1}$ ), but remains essentially unchanged at larger doses (up to eight times $\mathrm{ED}_{95}$ ) (from Casson and Jones ${ }^{38}$ ).

result, more than twice the mean adductor pollicis $\mathrm{ED}_{95}$ must be given to obtain adequate intubating conditions in all patients. A dose equal to three to four times $E D_{95}$ would appear more appropriate

Two factors limit the size of the dose which can be administered safely: the duration of paralysis and cardiovascular side effects. Both are important shortcomings of the long-acting non-depolarizing relaxants. Atracurium exhibits cardiovascular side effects with doses exceeding $0.5-0.6 \mathrm{mg} \cdot \mathrm{kg}^{-1}$. Its adductor pollicis $\mathrm{ED}_{95}$ is in the range $0.2-0.25 \mathrm{mg} \cdot \mathrm{kg}^{-1}$. ${ }^{22}$ Therefore, poor intubating conditions are often observed with $0.4-0.5 \mathrm{mg} \cdot \mathrm{kg}^{-1}$ even with complete abolition of adductor pollicis twitch height. ${ }^{41}$ Vecuronium is virtually devoid of cardiovascular side effects, and doses as high as $0.4 \mathrm{mg} \cdot \mathrm{kg}^{-1}$ (8 timcs $\mathrm{ED}_{95}$ ) have been administered to patients. ${ }^{38}$ With complete abolition of adductor pollicis twitch height, intubating conditions are often poor with $0.07 \mathrm{mg} \cdot \mathrm{kg}^{-1}$ of vecuronium (less than twice the $\mathrm{ED}_{95}$ ), but better with 0.14 or $0.28 \mathrm{mg} \cdot \mathrm{kg}^{-1}{ }^{10}$ Good to excellent intubating conditions can be achieved within a minute with $0.25 \mathrm{mg}$. $\mathrm{kg}^{-1}$ (approximately six times $\mathrm{ED}_{95}$ ). ${ }^{42}$ The major drawback of these high doses is a significant prolongation of neuromuscular blockade. This is particularly important during short surgical procedures or when tracheal intubation is not successful?

Little attention has been paid to the determination of the potency of succinylcholine, probably because of its short-lasting effect. Estimates of its $\mathrm{ED}_{95}$ vary between 0.2 and $0.3 \mathrm{mg} \cdot \mathrm{kg}^{-1},{ }^{4-45}$ much less than the $1-1.5 \mathrm{mg}$. $\mathrm{kg}^{-1}$ commonly employed for tracheal intubation. These data suggest that the excellent intubating conditions associated with the administration of the drug are largely due to high doses (three to seven times $\mathbf{E D}_{95}$ ) administered.

\section{Priming}

The priming technique consists in the administration of a small dose of non-depolarizing relaxant a few minutes before the paralyzing dose of the same or a different relaxant. ${ }^{41,46,47}$ The presumed role of the priming dose is to occupy a significant number of receptors before the paralyzing dose is administered. The onset of action should be more rapid because the paralyzing dose has a reduced number of receptors to block. Current evidence suggests that the administration of a priming dose does not increase the potency of neuromuscular blocking agents. ${ }^{48}$ A priming dose may be given to awake patients because a large number of receptors may be occupied without detectable neuromuscular blockade. ${ }^{27}$ Thus, the size of the priming dose should be small enough to produce neither detectable neuromuscular blockade nor significant symptoms in the awake individual. ${ }^{49,50} \mathrm{~A}$ useful guideline is to limit the amount of relaxant given to ten per cent of the $E D_{95}$ adductor pollicis dose. This is equivalent to d-tubocurarine, $0.04 \mathrm{mg} \cdot \mathrm{kg}^{-1}$ (3 $\mathrm{mg}$ in the $70 \mathrm{~kg}$ patient), atracurium, $0.02 \mathrm{mg} \cdot \mathrm{kg}^{-1}$, pancuronium, $0.007 \mathrm{mg} \cdot \mathrm{kg}^{-1}$ or vecuronium, $0.005 \mathrm{mg} \cdot \mathrm{kg}^{-1}$. There is no doubt that larger priming doses would be more effective in shortening the onset time, ${ }^{47,49}$ but the benefits anticipated from this acceleration do not justify this increase in dose. It should be stressed that the size of the intubating dose should in no circumstances determine the size of the priming dose. It is not appropriate to administer ten per cent of the intended intubating dose, especially if the total dose is many times $E_{95}$. For example, giving $0.02 \mathrm{mg}$ $\mathrm{kg}^{-1}$ before $0.18 \mathrm{mg} \cdot \mathrm{kg}^{-1}$ of vecuronium can lead to disaster. ${ }^{51}$

The most appropriate priming interval is in the range 3-5 min. ${ }^{47}$ This corresponds to 5-7 min before the intended time of tracheal intubation, and coincides with the peak action of the priming dose. With a 3-5 min priming interval, the effectiveness of the priming technique depends on the size of the intubating dose. If an $\mathrm{ED}_{95}$ dose is administered, a $20-30$ second acceleration 
can be demonstrated..$^{52,53}$ However, this dose is insufficient to provide uniformly acceptable intubating conditions, and the time required to maximum blockade is too long. Increasing the total dose while keeping the priming dose constant would shorten the onset time and improve intubating conditions, but would also reduce the relative contribution of the priming dose. Thus, although the priming technique undoubtedly works, it provides a marginal acceleration of onset time, given the doses administered in practice.

\section{Monitoring}

The monitoring of the adductor pollicis muscle has serious drawbacks in the assessment of the onset of neuromuscular blockade. Firstly, the sensitivity of the adductor pollicis muscle is usually greater than the upper airway and respiratory muscles which must be relaxed to oblain adequate intubating conditions. Secondly, peripheral muscles are not as well perfused as those lacated more centrally. These two opposing factors have different combined effects depending on the dose administered. If a large dose is given (at least three times $\mathrm{ED}_{95}$, equivalent to $0.15 \mathrm{mg} \cdot \mathrm{kg}^{-1}$ of vecuronium or $1 \mathrm{mg} \cdot \mathrm{kg}^{-1}$ of succinylcholine), the amount of drug administcred is probably sufficient to block all ruscles. Therefore, onset time will be faster in central than peripheral muscle, and good intubating conditions will probably occur before disappearance of the twitch at the adductor pollicis. However, if a relatively small dose is given, it may block the adductor pollicis without paralyzing respiratory muscles completely. In this case, the absence of neuromuscular activity at the adductor pollicis will not be indicative of adequate intubating conditions.

It follows that the presence of excellent intubating conditions cannot be guaranteed by the use of peripheral nerve stimulation. At present, only an educated guess can be made, based on the dose given. Ideally, at least three to four times the $\mathrm{ED}_{95}$ of the drug chosen should be injected, and the wait period should be $1-1.5 \mathrm{~min}$ for succinylcho line and 2-3 min for non-depolarizing relaxants. This time delay should be adjusted depending on age, estimate of cardiac output, and cardiovascular effects of the induction agent.

\section{Conclusion}

Even with the introduction of the priming technique, the time course of succinylcholine blockade is thus far unrivalled. ${ }^{54}$ Large doses may be administered to obtain profound relaxation without undue concern about recovery. However, many clinicians prefer the use of atracurium or vecuronium because of the side effects of succinylcholine. The induction technique must then allow for the longer onset time of the non-depolarizing blockers and the inadvisability of administering large doses for short duration procedures. Until a shorter acting non-depolarizer is available, anaesthetists will have to choose and base their decision on their own experience, the expected duration of the procedure, and most importantly, a good evaluation of the patient.

\section{Keferences}

I Miller RD, Way WL. The interaction between succinylcholine and subparalyzing doses of d-tubocurarine and gallamine in man. Anesthesiology 1971; 35: 567-71.

2 Culien $D J$. The effect of pretreatment with nondepolarizing muscle relaxants on the neuromuscular blocking action of succinylcholine. Anesthesiology 1971; 35: $572-8$.

3 Blackburn CL, Morgan M. Comparison of speed of onset of fazadinium, pancuronium, tubocurarine and suxamethonium. Br J Anaesth 1978; 50: 361-4.

4 Ferguson A, Bevan DR. Mixed neuromuscular block. The effect of precurarization. Anaesthesia 1981; 36: 661-6.

5 Blit $C D$, Carlson GL, Rolling GD, Hameroff $S R$, Otto $C W$. A comparative evaluation of pretreatment with nondepolarizing neuromuscular blockers prior to the administration of succinylcholine. Anesthesiology 1981; 55: $687-9$

6 Gergis SD, Sokoll MD, Mehta M, Kemmotsu O, Rudd GD. Intubation conditions after atracurium and suxamethonium. BI J Anaesth 1983; 55: 83S-6S.

7 Manchicanti L, Grow JB, Colliver JA, Canella $M G$, Hadley $\mathrm{CH}$. Atracurium pretreatment for succinylcholineinduced fasciculations and postoperative myalgia. Anesth Analg 1985; 64: 101-4.

8 Duranr NN, Katz RL. Suxamethonium. Br I Anaesth 1982; 54: 195-208.

9 Donati F, Bevan DR. Suxamethonium - current status. Clin Anaesthesiol 1985; 3: 371-85.

10 Fahey MR, Morris RB, Miller RD, Sohn YJ, Cronnetly R, Gencarelli $P$. Clinical pharmacology of ORG NC45 (Norcurun): a new nondepolarizing muscle relaxant. Anesthesiology 1981; 55: 6-11.

11 Mirakhur RK, Ferres CJ, Clarke RSJ, Bali $M$, Dundee $J W$. Clinical evaluation of ORG NC45. Br J Anaesth $1983 ; 55: 119-24$

12 Healy TEJ, Pugh ND, Kay B, Sivalingham T, Petts HV. Atracurium and vecuronium: effect of dose on time of onset. Br J Anaesth 1986; 58: 620-4.

13 Harrison GA, Jurtius $F$. The effect of eirculation time on the neurornuscular action of suxamethonium. Anaesth Intensive Care 1972; 1: 33-9.

14 Bevan JC. Donati $F$, Bevan $D R$. Attempted acceleration of the onset of pancuronium. Effect of divided doses in infants and children. $\mathrm{Br} J$ Anaesth 1985; 57: 1205-8.

15 Smith CE, Baxter M, Bevan JC, Donati F, Bevan DR 
Accelerated onset and delayed recovery of d-tubccurarine blockade with pancuronium priming in infants and children. Can J Arlaesth 1987; 34: 555-9.

16 Donati $F$, Bevan DR. The influence of patient's sex, age and weight on pancuronium onset time. Can Anaesth Soc $\mathbf{J}$ 1986; 33: 586.

17 Chauvin M, Lebreault $C_{1}$ Davaldestin $P$. The neuromuscular blocking effect of vecuronium on the human diaphragm. Anesth Analg 1987; 66: 117-22.

18 Pansard $J L, C h a u v i n M$, Lebreault $C$, Gaumeau $P$, Duvaldestin $P$. Effect of an intubating dose of succinylcholine and atracurium on the diaphragm and the adductor pollicis. muscle in humans. Anesthesiology 1987; 67: 326-30.

19 Goat VA, Yeung ML, Blakeney C, Feldman SA. The effect of blood flow upon the activity of gallamine triethiodide. $\mathrm{Br}$ J Anaesth 1976; 48: 69-73.

20 Saxena PR, Dhasmana KM, Prakash O. A comparison of systemic and regional hemodynamic effects of d-tubocurarine, pancuronium, and vecuronium. Anesthesiology 1983; 59: 102-8.

21 Curran MJ, Donati F, Bevan DR. Onset and recovery of atracurium and suxamethonium-induced neuromuscular blockade with simultaneous train-of-four and single I witch stimulation. Br J Anaesth 1987; 59: 989-94.

22 Shank. CA. Pharmacakinetics of the nondepolarizing neuromuscular relaxants applied to the calculation of bolus and infusion dosage regimens. Anesthesiology 1986; 64: 72-86.

23 Cohen EN, Corbascio A, Fleischli G. The distribution and fate of d-tubocurarine. J Pharnacol Exp Ther 1965; 147: $120-9$.

24 Stunski DR, Ham J, Milier RD, Sheiner LB. Pharmacokinetics and pharmacodynamics of d-tubocurarine during nitrous oxide-narcotic anesthesia in man. Anesthesiology 1979; 51: 235-41.

25 Eccles JC, Jaeger JC. The relationship between the mode of operation and the dimension of the junctional regions at synapses and motor end-organs. Proc Roy Soc B 1958; 148: 38-56.

26 Armstrong $D L$, Lester HA. The kinetics of d-tubocurarine action and restricted diffusion within the synaptic cleft. J Physiol (Lond) 1979; 294: 365-86.

27 Poton WDM, Waud DR. The margin of safety of neuromuscular transmission. J Physiol (Lond) 1967; 191: 59-90.

28 .Minsaas B. Stowner J. Artery-to-musele onset time for neuromuscularblockingdrugs. BrJ Anacsth 1980;52:403-7.

29 Hull CJ, Van Beem HBH, McLeod K, Sibbald A, Watson MJ. A pharmacodynamic model for pancuronium. $\mathrm{Br} \mathrm{J}$ Anaesth 1978; 50: 1113-22.

30 Sheiner LB, Stanski DR, Vozeh S, Miller RD, Ham J. Simultaneous modeling of pharmacokinetics and dynamics: application to d-tubccurarine. Clin Pharmacol Ther 1979; 25: 358-71.
31 Hennis PJ, Stanski DR. Pharmacokinctic and pharmacodynamic factors that govern the clinical use of muscle relaxants. Sem Anesth 1985; 4: 21-30.

32 Fisher DM, Castagnoli $K$, Miller RD. Vecuroniun kinetics and dynamics in anaesthetized infants and children. Clin Pharmacol Ther 1985; 37: 402-6.

33 Weatherley BC, Williams SG. Neill EAM. Pharmacokinetics, pharmacodynamics and dose-response relationships of atracunum administered I. V. Br J Anacsth 1983; 55: 39S-45S.

34 Gramstad L, Lileaasen $P$, Minsaas $B$. Onset time and duration of action for atracurium, ORG NC 45 and pancuronium. Br J Anaesth 1982; 54: 827-30.

35 Cass NM, Doolan LA, Gwtteridge GA. Repeated adminstration of suxamethonium in a patient with atypical cholinesterase. Anaesth Intensive Care 1982; 10:25-8.

36 Hickey DR, O' Connor JP, Donati $F$. Comparison of atracurium and succinylcholine for electroconvulsive therapy in a patient with atypical cholinesterasc. Can $J$ Araesth 1987; 34: 280-3.

37 Basta SJ, Savarese JJ, Ali HH et al. The neuromuscular pharmacology of NW B1090U in anesthetized patients. Auesthesiology 1985; 63: A318.

38 Casson WR, Jones RM. Vecuronium induced neuromuscular blockade. The effect of increasing dose on speed of onset. Anaesthesia 1986; 41: 354-7.

39 Donati $F$, Antzaka C. Bevan DR. Poltency of paneuronium at the diaphragm and the adductor pollicis muscle in humans. Anesthesiology 1986; 65: 1-5.

40 Laycock JRD. Dontati F, Bevan DR. Potency of atracurium and vecuronium at the diaphragm and adductor pollicis muscle in humans. Br J Anaesth 1987; 59: $1321 \mathrm{P}$.

41 Naguib M, Abdullatif $M$, Absood GH. The optimal priming dose for atracurium. Can Anaesth Soc J 1986; 33: 453-7.

42 Lennon RL, Olson RA, Gronert GA. Atracurium or vecuronium for rapid sequence endotracheal intubation. Anesthesiology 1986; 64: 510-3.

43 Miller RD, Way WL, Dolan WM, Stevens WC, Eger El II Comparative neuromuscular effects of pancuronium, gallamine, and succinylcholine during Forane and halothane anesthesia in man. Anesthesiology 1971; 35: 509-14.

44 Cook DR. Pharmacokinetics of succinylcholine in infants, children and adults. Clin Pharmacol Ther 1976; 20: 493-8.

45 Smith CE, Donati F, Bevan DR. Dose response curves for succinylcholine: single versus cumulative techniques. Anesthesiology 1987; 67: A358.

46 Schwarz $S$, Ilias $W$, Lackner F, Mayhofer $O$, Foldes FF. Rapid tracheal incubation with vecuronium: the priming principle. Anesthesiology 1985; 62: 388-91.

47 Taboada JA, Rupp SM, Miller RD. Refining the priming principle for vecuronium during rapid-sequence induction of anesthesia. Anesthesiology 1986; 64: 243-7. 
48 Brady MM, Mirakhur RK, Gibson FM. Influence of "priming" on the potency of non-depolarizing neuromuscular blocking agents. Br J Anaesth 1987; 59; 1145-9.

49 Engbaek J, Howardy-Hansen P, Ørding H, Viby-Mogensen J. Precurarization with pancuronium and vecuronium in awake, healthy volunteers: the infiuence on reuromuscular transmission and pulmonary function. Acta Araesthesiol Scand 1985; 29: 117-20.

50 Sosis M, Larijani GE, Marra AT. Priming with atracurium. Anesth Analg 1987; 66: 329-32.

51 Musich $J$, Walts LF. Pulnunary aspiration after a priming dose of vecuronium. Anesthesiology 1986; 64: 517-9.

52 Black AMS, Hutton P, El-Hassen M, Morgan G, CluttonBrock $T H$. Priming and the onset of neuromuscular blockade with alcuronium. Br J Anaesth 1986; 58: 827-33.

53 Doherty WG, Breen $P J$, Donati $F$, Bevan DR. Accelerated onset of pancuronium with divided doses. Can Anaesth Soc J $1985 ; 32 ; 1-4$.

54 Marrin C, Bonneru JJ, Brun JP, Albanese J, Gouin F. Vecuronium or suxamethonium for rapid sequence intubation: which is better? Br J Anaesth 1987; 59: 1240-4. 